\title{
Article \\ Source and Accumulation of Soil Carbon along Catena Toposequences over 12,000 Years in Three Semi-Natural Miscanthus sinensis Grasslands in Japan
}

\author{
David S. Howlett ${ }^{1}$, J. Ryan Stewart ${ }^{2}$, Jun Inoue ${ }^{3} \mathbb{D}$, Masanori Saito ${ }^{4} \mathbb{D}$, DoKyoung Lee ${ }^{5}$, Hong Wang ${ }^{6}$, \\ Toshihiko Yamada ${ }^{7}$ (D) Aya Nishiwaki ${ }^{8}$, Fabián G. Fernández ${ }^{9}$ iD and Yo Toma ${ }^{10, *}$
}

Citation: Howlett, D.S.; Stewart, J.R.; Inoue, J.; Saito, M.; Lee, D.; Wang, H.;

Yamada, T.; Nishiwaki, A.;

Fernández, F.G.; Toma, Y. Source and Accumulation of Soil Carbon along Catena Toposequences over 12,000 Years in Three Semi-Natural Miscanthus sinensis Grasslands in Japan. Agriculture 2022, 12, 88. https://doi.org/10.3390/ agriculture 12010088

Academic Editor: Claudia Di Bene

Received: 21 November 2021

Accepted: 31 December 2021

Published: 10 January 2022

Publisher's Note: MDPI stays neutral with regard to jurisdictional claims in published maps and institutional affiliations.

Copyright: (C) 2022 by the authors. Licensee MDPI, Basel, Switzerland. This article is an open access article distributed under the terms and conditions of the Creative Commons Attribution (CC BY) license (https:// creativecommons.org/licenses/by/ $4.0 /)$.
1 United States Agency for International, 1300 Pennsylvania Avenue, NW, Washington, DC 20523, USA; davhowlett@gmail.com

2 Department of Plant and Wildlife Sciences, Brigham Young University, 2124 LSB, Provo, UT 84602, USA; rstewart@byu.edu

3 Graduate School of Science, Osaka City University, 3-138 Sugimoto, Sumiyoshi-ku, Osaka 558-8585, Japan; juni@sci.osaka-cu.ac.jp

4 Graduate School of Agricultural Science, Tohoku University, Osaki 989-6711, Japan; masanori.saito.b6@tohoku.ac.jp

5 Department of Crop Sciences, University of Illinois at Urbana-Champaign, Turner Hall, 1102 S Goodwin Ave, Urbana, IL 61801, USA; leedk@illinois.edu

6 Interdisciplinary Research Center of Earth Science Frontier, Beijing Normal University, Beijing 100875, China; hongwang@bnu.edu.cn

7 Field Science Center for Northern Biosphere, Hokkaido University, Kita-11, Nishi-10, Kita-ku, Sapporo 060-0811, Japan; yamada@fsc.hokudai.ac.jp

8 Field Science Center Kibana Agricultural Science Station, Faculty of Agriculture, University of Miyazaki, 1-1, Gakuen-Kibanadai-Nishi, Miyazaki 889-2192, Japan; nishiwaki@cc.miyazaki-u.ac.jp

9 Department of Soil, Water and Climate, University of Minnesota, 1529 Gortner Avenue, St. Paul, MN 55108, USA; fabiangf@umn.edu

10 Research Faculty of Agriculture, Hokkaido University, Kita-9, Nishi-9, Kita-ku, Sapporo 060-8589, Japan

* Correspondence: toma@chem.agr.hokudai.ac.jp; Tel.: +81-11-706-3857

\begin{abstract}
Miscanthus-dominated semi-natural grasslands in Japan appear to store considerable amounts of soil C. To estimate the long-term effect of Miscanthus vegetation on the accumulation of soil carbon by soil biota degradation in its native range, we measured total soil $C$ from the surface to a $1.2 \mathrm{~m}$ depth along a catena toposequence in three annually burned grasslands in Japan: Kawatabi, Soni, and Aso. Soil $\mathrm{C}$ stock was estimated using a radiocarbon age and depth model, resulting in a net soil $C$ accumulation rate in the soil. $C_{4}$-plant contribution to soil $C$ accumulation was further estimated by $\delta^{13} \mathrm{C}$ of soil $\mathrm{C}$. The range of total soil $\mathrm{C}$ varied among the sites (i.e., Kawatabi: 379-638 Mg, Soni: 249-484, and Aso: $372-408 \mathrm{Mg} \mathrm{C} \mathrm{ha}^{-1}$ ). Catena position was a significant factor at Kawatabi and Soni, where the toe slope soil $\mathrm{C}$ accumulation exceeded that of the summit. The soil $\mathrm{C}$ accumulation rate of the whole horizon in the grasslands, derived $\mathrm{C}$ mainly from $\mathrm{C}_{4}$ plant species, was $0.05 \pm 0.02$ (Average $\pm \mathrm{SE}$ ), $0.04 \pm 0.00$, and $0.24 \pm 0.04 \mathrm{Mg} \mathrm{C}^{-1} \mathrm{yr}^{-1}$ in Kawatabi, Soni, and Aso, respectively. Potential exists for long-term sequestration of $C$ under $M$. sinensis, but the difference in the $\mathrm{C}$ accumulation rate can be influenced by the catena position and the amount of vegetation.
\end{abstract}

Keywords: Miscanthus sinensis; soil carbon; catena; radiocarbon dating; $\mathrm{C}_{4}$ grasses

\section{Introduction}

Miscanthus, a cold-tolerant perennial grass $\mathrm{C}_{4}$ native to East and Southeast Asia, exhibits potential as a feedstock for the production of biofuels and bio-based products [1-4]. As such, this genus may see a considerable increase in cultivation in the United States and Europe in the coming years. In order to estimate the potential effects on edaphic resources, 
several researchers have considered the impact this genus has on soil carbon, mostly in cultivated or fallow fields [5-9]. Observations, however, from these studies have been limited to less than 20 years. Semi-natural Miscanthus sinensis grasslands in Japan, some of which have been managed for hundreds of years [4], offer an opportunity to assess the effects of centuries of Miscanthus growth and management on soil C resources [10-15].

Miscanthus utilizes the efficient $\mathrm{C}_{4}$ photosynthetic pathway and, consequently, the origin of organic inputs to the soil from plants in this genus can be determined via their stable isotopic composition $[9,16,17]$. Differences in the relative abundance of the ${ }^{13} \mathrm{C} /{ }^{12} \mathrm{C}$ ratio in plants that utilize the $\mathrm{C}_{4}$ photosynthetic pathway allow for determining the relative contribution by Miscanthus to soil C stocks [18]. Using stable $C$ isotopic analysis, Schneckenberger and Kuzyakov (2007) estimated Miscanthus C inputs ranging between 0.11 and $0.30 \mathrm{~g} \mathrm{C} \mathrm{kg} \mathrm{soil}^{-1} \mathrm{yr}^{-1}$ in a sandy versus loamy soil in Germany. Howlett et al. (2013) found that a majority of soil C, ranging between $52 \%$ and $85 \%$ at a depth up to $1.5 \mathrm{~m}$, was derived from Miscanthus in a Typic Melanudans in a southern Japanese Miscanthusdominated grassland. To estimate soil $\mathrm{C}$ accumulation over time, the relationship between soil depth and age needs to be determined. Dating of soil C in soil profiles with low $C$ content, however, is problematic. Bioturbation causes vertical mixing or movement of soluble $C$ compounds, and additions of heterogeneous sources of $C$ from land surface and groundwater reduce the integrity of age-to-depth models $[19,20]$. However, soils previously investigated in the same biome contained high $\mathrm{C}$ content and demonstrated highly correlated age-to-depth models $\left(R^{2}=0.98-0.99\right)$ [11]. Using these age-to-depth models, Howlett et al. (2013) estimated Miscanthus-derived soil C accumulation at $0.62-0.85 \mathrm{Mg} \mathrm{C} \mathrm{ha}^{-1} \mathrm{yr}^{-1}$ down to a $1.5 \mathrm{~m}$ depth in a Miscanthus-dominated semi-natural grassland in southern Japan.

In volcanic regions with diverse topography where ash accumulation and other formative materials, such as humus, are subject to erosion and deposition processes along the continuum of different landscape positions [21], a soil catena study that encompasses hillside summits, mid-slopes, and toe slopes can shed valuable information on $\mathrm{C}$ accumulation phenomena. The dynamics of $C$ associated with these topographic forms have previously been considered. Schimel et al. (1985) [22] reported double the surface soil C on lower foot slopes relative to that found in summit soils in Colorado, USA. While fully vegetated grasslands may not experience a considerable amount of erosion, the annual burning associated with traditionally managed Miscanthus grasslands in Japan removes the vegetative cover that protects soil from erosion $[11,13]$. Precipitation events following these traditional burnings redistributes $\mathrm{C}$-containing sediments lower into the watershed, and soils developed on lower positions on a slope may demonstrate higher levels of soil $C$ due to the fact of depositional processes. As soil from organic horizons erode and C-containing sediment accumulates below, the catena concept provides utility in characterizing the potential variability of soil C within the varied topography of many Japanese Miscanthus grasslands. Understanding the variability and accumulation of soil $\mathrm{C}$ underlying Miscanthus grasslands in Japan will help to determine whether there is greater benefit in growing Miscanthus as a soil C sequestration bioenergy crop or to serve alternative purposes such as a traditional landscape for ecotourism. Our efforts to identify the long-term impacts of Miscanthus on soil C deposition involved a three-pronged approach: (1) estimate the effect of catena position on the development of $C$ stocks to $1.2 \mathrm{~m}$ underlying three semi-natural grassland catenas currently dominated by $M$. sinensis in Japan, (2) quantify the relative contribution of $M$. sinensis to these $C$ stocks, and (3) calculate the rate of soil $C$ accumulation contributed by M. sinensis.

\section{Materials and Methods}

\subsection{Site Descriptions}

Three grasslands sites were chosen based on their current dominance by M. sinensis and for a latitudinal gradient across Japan (Figure 1a). 


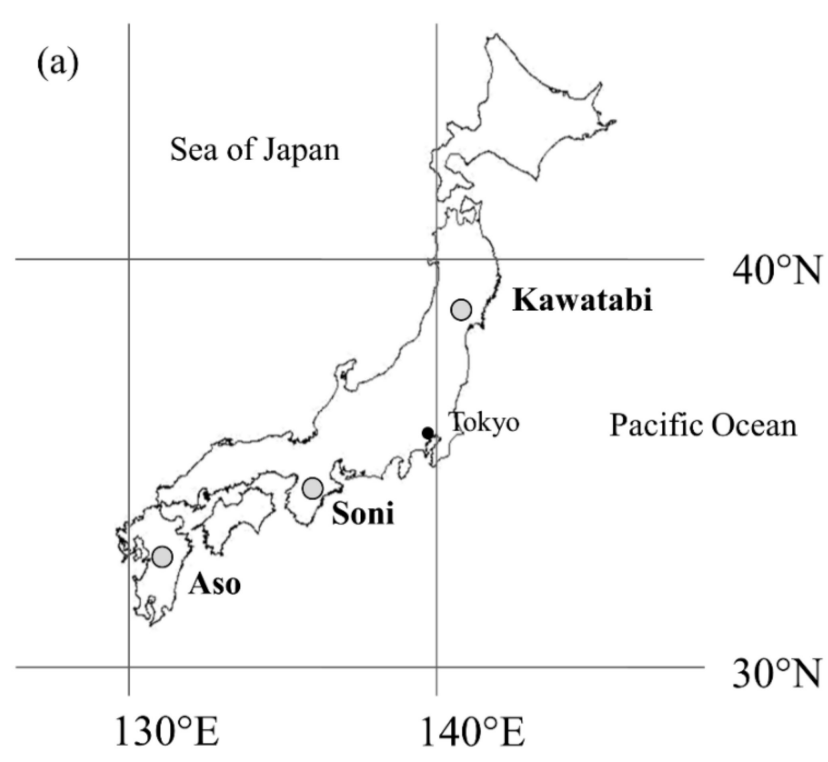

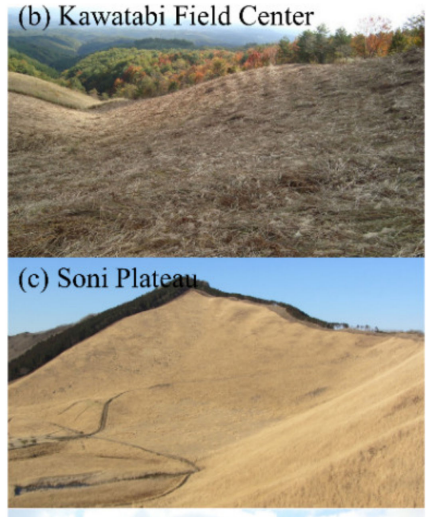

(d) Aso-Kuju National Park

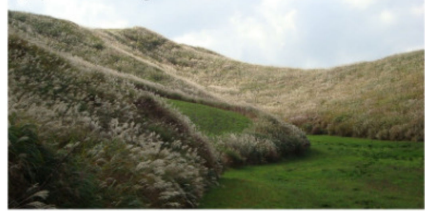

Figure 1. Locations of the semi-natural Miscanthus sinensis grassland study sites in Japan (a) and the semi-natural Miscanthus grassland study sites of the Kawatabi Field Science Center, Miyagi Prefecture (b); Soni Plateau, Nara Prefecture (c); Aso-Kuju National Park, Kumamoto Prefecture (d).

\subsubsection{Kawatabi}

The northernmost sampling site was at the Kawatabi Field Science Center of Tohoku University, located near the Kawatabi natural springs (KAW), Miyagi Prefecture, Japan $\left(38^{\circ} 46.25^{\prime} \mathrm{N}, 140^{\circ} 45.16^{\prime} \mathrm{E}, 550 \mathrm{~m}\right.$ a.s.l., approximately $14^{\circ}$ of the slope), where the mean annual temperature is $11^{\circ} \mathrm{C}$, and there is a mean annual precipitation of $1460 \mathrm{~mm}$ [23] (Figure $1 b$ ). The site is dominated by $M$. sinensis, which is maintained by annual mechanical cutting in the fall with the grass left in place after cutting. Burning as a maintenance practice in this site ceased more than 40 years ago. Ito and Saigusa (1996) described several soil profiles from this site. One key aspect of this site is the documented non-allophanic chemistry of the Andisols. High contents of Al and Fe help to retain relatively large amounts of organic matter facilitating the formation of stable organo-mineral complexes, which likely also occur at the other two sites.

\subsubsection{Soni Plateau}

The middle latitude site was within the grasslands at the Soni Plateau (SONI) in Nara Prefecture, Japan $\left(34^{\circ} 31.07^{\prime} \mathrm{N}, 136^{\circ} 09.80^{\prime} \mathrm{E}, 720 \mathrm{~m}\right.$ a.s.l. approximately $30^{\circ}$ of the slope), where the mean annual temperature is $12^{\circ} \mathrm{C}$, and it has a mean annual precipitation of $1720 \mathrm{~mm}$ (Figure 1c). The M. sinensis-dominated grasslands is maintained by annual burning in the spring, and the area is a tourist destination for recreation and ecotourism. Soils are also Typic Andisols with contents of volcanic glass [24]. Inoue et al. (2012) [24] and Okunaka et al. (2012) [25] reconstructed the vegetative history of the site, with $M$. sinensis becoming dominant on the site 1500 years ago.

\subsubsection{Aso-Kuju}

The southern-most site is within the grasslands of the Aso-Kuju National Park (ASO) in Kumamoto Prefecture, Japan $\left(32^{\circ} 55.75^{\prime} \mathrm{N}, 131^{\circ} 09.60^{\prime} \mathrm{E}, 843 \mathrm{~m}\right.$ a.s.1., approximately $21^{\circ}$ of the slope), where the mean annual temperature is $13{ }^{\circ} \mathrm{C}$, and it has a mean annual precipitation of $3200 \mathrm{~mm}$ (Figure $1 \mathrm{~d}$ ). The M. sinensis-dominated site is considered a seminatural grassland, which has been annually burned for hundreds of years in early spring in order to maintain the Miscanthus-grassland ecosystem $[4,13,26]$. No additional management has taken place other than burning for at least 50 years [11]. The Miscanthus grasslands of 
Aso-Kuju National Park are a tourist destination partly due to the rarity of grasslands in Japan. Moreover, ecotourism during the burning season significantly contributes to the local economy. Soils in this region are typical of Japan, derived from volcanic ash and characterized by the USDA soil classification system as Typic Melanudans [27]. A diagnostic general characteristic of these soils is the presence of a $2 \mathrm{AB}(\mathrm{K}-\mathrm{Ah})$ volcanic deposit at approximately $60-70 \mathrm{~cm}$ depths in many parts of the caldera, which has been dated to a local volcanic eruption event by Mount Kikai approximately 7300 years ago [15,28].

\subsection{Field Collections}

At each of the three sites, soils were sampled at $10 \mathrm{~cm}$ increments down to $120 \mathrm{~cm}$, following a hillside catena sequence transect, representing the summit, mid-, and toe slope. Transect lengths were 200-250 m from the toe slope to the summit. Replicate soil samples were taken $3 \mathrm{~m}$ on the left- and right-hand sides of each catena location (facing the summit). We selected the east and west slope aspects at each site to avoid known edaphic differences between north- and south-facing slopes. The slopes of the catena sequences varied among the sites, and the mean percent slope was calculated by dividing vertical distance from the summit to the toe slope by the transect distance. The mean percent slopes were $29 \%$ in $\mathrm{KAW}, 36 \%$ in SONI, and 18\% in ASO. In total, 27 soil catenas were examined (three sites, three catena positions, and three replicates per catena position).

To estimate bulk density, a metal canister of a known volume (i.e., $100 \mathrm{~cm}^{3}$ ) was inserted into the soil profile and removed with an undisturbed soil core at four representative depths $(15,45,75$, and $105 \mathrm{~cm}$, which were the midpoints for 0-30, 30-60, 60-90, and 90-120 cm soil depths). Bulk density samples were dried at $100{ }^{\circ} \mathrm{C}$ to a consistent weight.

\subsection{Laboratory Procedures}

Soil samples from each of the $10 \mathrm{~cm}$ depth increments for soil $\mathrm{C}$ content analysis were immediately stored in temperature-controlled conditions and then air-dried to a constant weight. Air-dried soils were passed through a $2 \mathrm{~mm}$ sieve, and subsamples were taken for determination of moisture content. Soil $\mathrm{C}$ content was determined by combustion of $2 \mathrm{~mm}$ sieved soil in an elemental analyzer (Leco CN Analyzer, St. Joseph, MI, USA).

Stable isotopic $\mathrm{C}$ composition and accelerator mass spectrometer (AMS) radiocarbon ages were determined for five soil depth increments: 0-10, 20-30, 50-60, 80-90, and $110-120 \mathrm{~cm}$ at each of the catena positions at all three sites. Soil samples with high organic $C$ content were pretreated using the standard acid-base-acid (ABA) method as described by Brandt et al. (2012) [29]. The same pretreatment method was also applied to radiocarbonfree wood, IAEA (International Atomic Energy Agency) C5 wood, and FIRI-D (Fifth International Radiocarbon Inter-Comparison D) woodworking standards. Approximately $0.5 \mathrm{~g}$ of soil, $3-5 \mathrm{mg}$ of working standards, and $200-300 \mathrm{mg}$ of $\mathrm{CuO}$ granules were placed into preheated quartz tubes for sealed quartz tube combustion at $800{ }^{\circ} \mathrm{C}$. Quartz tubes were preheated at $800{ }^{\circ} \mathrm{C}$ for $2 \mathrm{~h}$, and $\mathrm{CuO}$ granules were preheated at $800^{\circ} \mathrm{C}$ one day before usage. Combustion was set for $2 \mathrm{~h}$ at $80{ }^{\circ} \mathrm{C}$. Samples were then cooled slowly from 800 to $600{ }^{\circ} \mathrm{C}$ for $6 \mathrm{~h}$ to allow $\mathrm{Cu}$ to reduce the $\mathrm{NxO}$ to nitrogen gas. Purified $\mathrm{CO}_{2}$ was collected cryogenically under vacuum conditions, which were less than 10 mTorr, and submitted to the Keck Carbon Cycle AMS Laboratory of the University of California-Irvine for AMS ${ }^{14} \mathrm{C}$ analysis using the hydrogen-iron reduction method with ${ }^{13} \mathrm{C}$ values measured on prepared graphite [30]. All results were corrected for isotopic fractionation according to the conventions of Stuiver and Polach (1977) [31]. Sample preparation backgrounds were subtracted based on the measurements of radiocarbon-free wood blanks. The results indicated that after background subtraction, IAEA-C5 and FIRI-D wood reference materials yielded target values within $1 \sigma$ deviations. Radiocarbon dating data greater than $100 \%$ of modern C were considered as present C, which was fixed from 1950 to 2012.

Soil texture was determined using the laser diffraction method [32]. Soil $\mathrm{pH}$ was measures in a 1:1 ratio of soil to water. Plant-available, exchangeable potassium, magnesium, and calcium were determined with the Bray-1 extraction method [33]. The content 
of cations, cation exchange capacity, and percent base saturation of cation elements were calculated from extract results.

\subsection{Calculations}

Bulk density, estimated by dividing the oven-dried mass (g) by the canister volume, C content in $<2 \mathrm{~mm}$ bulk soil (\%), and the soil bulk density $\left(B D, \mathrm{~g} \mathrm{~cm}^{-3}\right)$, was used to estimate soil $\mathrm{C}$ stock per $10 \mathrm{~cm}$ depth increments $\left(\mathrm{Mg} \mathrm{C} \mathrm{ha}^{-1}\right)$.

$$
\text { Soil } C \text { stock }=\text { Soil } C \text { content } \times B D \times 10,
$$

To estimate $C_{4}$ plant contribution to soil $C, \delta^{13} C$ of soil $C\left(\delta^{13} C_{S C}, \%\right)$ were calculated as follows:

$$
\delta^{13} C_{S C}=\left[\left(R_{\text {sample }} / R_{\text {standard }}-1\right)\right] \times 1000,
$$

where $R$ is the ratio of ${ }^{13} \mathrm{C} /{ }^{12} \mathrm{C}$ in bulk soil C. The standard was V-PeeDee Belemnite (V-PDB) carbonate. The measured $\delta^{13} \mathrm{C}$ values were converted to relative abundances of $\mathrm{C}_{3}$ and $\mathrm{C}_{4}$ plants using the mass balance equation:

$$
\delta^{13} C_{S C}=\left\{\left(\delta^{13} C_{C 4}\right) \times x\right\}+\left\{\left(\delta^{13} C_{C 3}\right) \times(1-x)\right\},
$$

where $x$ indicates the ratios of $C$ source derived from $C_{4}$ and $C_{3}$ plants, which were $-13 \%$ o and $-27 \%$, respectively, and were used as the average values of $\delta^{13} C_{C 4}$ and $\delta^{13} C_{C 3}$ for calculation.

Linear regression, completed using PROC REG in SAS (version 9.2, Carey, NC, USA), was used to estimate soil $C$ age at various soil depths with $p<0.05$. The goodness of model fit and significance were estimated by $R^{2}$ and $p$-values. Profile summaries were calculated from the summed $C$ stock for each treatment combination. Sampling sites were not compared, and only the catena position effect was assessed for total soil $\mathrm{C}$ and $\mathrm{C}_{4}$-source $C$ within each soil depth at each site (ANOVA, PROC GLM in SAS).

Accumulation of $\mathrm{C}_{4}-\mathrm{C}\left(C_{f l u x}, \mathrm{MgC} \mathrm{ha}^{-1} \mathrm{yr}^{-1}\right)$ was calculated using soil $\mathrm{C}$ content $\left(\mathrm{g} \mathrm{C} 100 \mathrm{~g}^{-1}\right)$, sedimentation rates ( $\mathrm{SR}, \mathrm{cm} \mathrm{yr}^{-1}$, from the surface down to $1.2 \mathrm{~m}$ ), $B D$, and $x$, which is the $\mathrm{C}_{4}$-derived $\mathrm{C}$ content from ${ }^{13} \mathrm{C}$ abundance in Equation (3) as follows:

$$
C_{f l u x}=\text { Soil } C \text { content } \times S R \times B D \times x,
$$

Combined with the known depth of each of the soil profiles and C stock data, radiocarbon dating of the profiles was used to generate age-depth models to estimate the sedimentation rate to $1.2 \mathrm{~m}$ for total $\mathrm{C}$ and $\mathrm{C}$ from $\mathrm{C}_{4}$ plant sources as per the methods of Howlett et al. (2013). The risk exists for $\delta^{13} C$ to become less negative due to the fact of isotopic fractionation, which could introduce uncertainty in determining the contribution of $C$ from $C_{3}$ and $C_{4}$ plants. However, degradation-induced fractionation is essentially negligible, because new additions of organic $\mathrm{C}$ in the mesic Miscanthus-grassland ecosystem generally overwhelm the oxidation of the soil organic $C$ pool. Moreover, decomposition only enriches less than $1-2 \%$ for soils in dry and/or hot environments, which was not the case in our study.

\section{Results}

Selected soil physical and chemical properties are shown in Table 1. Values represent the averages of whole soil samples from the surface to a $1.2 \mathrm{~m}$ depth, because soil samples were collected at $10 \mathrm{~cm}$ soil depth increments and could not be presented by soil horizons. Selected soil physical and chemical properties show that the soils from the three Miscanthus sinensis-dominated grassland catenas were low in $\mathrm{pH}$, had a texture from silt to silt loam, and had low to moderate CEC (Table 1). Low BD is typical of volcanic ash-derived soils. 
Table 1. Soil physical and chemical properties (Average $\pm \mathrm{SD}$ ) underlying three Miscanthus sinensis grasslands in Japan (i.e., Kawatabi Field Science Center, Miyagi Prefecture (KAW); Soni Plateau, Nara Prefecture (SONI); Aso-Kuju National Park, Kumamoto Prefecture (ASO)).

\begin{tabular}{|c|c|c|c|c|c|c|c|c|c|c|}
\hline Site & $\begin{array}{c}\text { Depth } \\
\text { (cm) }\end{array}$ & $\begin{array}{l}\text { Clay } \\
(\%)\end{array}$ & $\begin{array}{l}\text { Silt } \\
(\%)\end{array}$ & $\begin{array}{l}\text { Sand } \\
(\%)\end{array}$ & $\begin{array}{c}\text { Bulk } \\
\text { Density } \\
\left(\mathrm{g} \mathrm{cm}^{-3}\right)\end{array}$ & $\mathrm{pH}$ & $\begin{array}{l}\mathrm{CEC} \S \\
\left(\mathrm{cmol}_{\mathrm{c}}\right. \\
\left.\mathrm{kg}^{-1}\right)\end{array}$ & $\begin{array}{c}\text { Ex. }{ }^{+} \mathrm{K} \\
(\%)\end{array}$ & $\begin{array}{c}\text { Ex. Mg } \\
(\%)\end{array}$ & $\begin{array}{c}\text { Ex. Ca } \\
(\%)\end{array}$ \\
\hline \multirow[t]{4}{*}{ KAW } & $0-30$ & $6.9 \pm 2.2$ & $88.1 \pm 0.9$ & $4.0 \pm 1.6$ & $0.5 \pm 0.0$ & $4.6 \pm 0.4$ & $103 \pm 118$ & $2.0 \pm 1.2$ & $5.0 \pm 4.6$ & $14.9 \pm 12.8$ \\
\hline & $30-60$ & $7.3 \pm 3.1$ & $88.2 \pm 2.5$ & $3.5 \pm 2.4$ & $0.6 \pm 0.3$ & $4.9 \pm 0.3$ & $13 \pm 8$ & $2.6 \pm 1.2$ & $16.3 \pm 13.7$ & $35.4 \pm 25.5$ \\
\hline & $60-90$ & $7.1 \pm 3.3$ & $75.4 \pm 16.7$ & $16.6 \pm 20.3$ & $0.8 \pm 0.4$ & $5.2 \pm 0.2$ & $8 \pm 8$ & $5.7 \pm 2.6$ & $24.7 \pm 10.9$ & $46.2 \pm 27.4$ \\
\hline & $90-120$ & $6.5 \pm 3.9$ & $78.4 \pm 5.6$ & $14.2 \pm 9.7$ & $0.9 \pm 0.2$ & $5.3 \pm 0.2$ & $9 \pm 7$ & $7.3 \pm 3.6$ & $27.2 \pm 15.7$ & $41.9 \pm 24.7$ \\
\hline \multirow[t]{4}{*}{ SONI } & $0-30$ & $8.9 \pm 0.8$ & $88.6 \pm 0.9$ & $1.2 \pm 0.1$ & $0.6 \pm 0.1$ & $5.3 \pm 0.1$ & $15 \pm 8$ & $20.0 \pm 10.1$ & $15.7 \pm 10.3$ & $22.5 \pm 16.2$ \\
\hline & $30-60$ & $6.5 \pm 4.1$ & $84.8 \pm 1.9$ & $7.9 \pm 5.5$ & $0.9 \pm 0.3$ & $5.2 \pm 0.1$ & $4 \pm 1$ & $14.4 \pm 8.2$ & $28.5 \pm 2.7$ & $57.1 \pm 5.4$ \\
\hline & $60-90$ & $8.0 \pm 4.6$ & $85.3 \pm 5.1$ & $5.9 \pm 0.2$ & $1.0 \pm 0.2$ & $5.4 \pm 0.2$ & $4 \pm 1$ & $10.1 \pm 2.7$ & $31.9 \pm 3.0$ & $57.9 \pm 4.7$ \\
\hline & $90-120$ & $8.3 \pm 3.8$ & $84.2 \pm 3.9$ & $6.6 \pm 5.5$ & $1.1 \pm 0.1$ & $5.6 \pm 0.1$ & $4 \pm 1$ & $13.9 \pm 13.7$ & $28.7 \pm 4.6$ & $57.4 \pm 9.1$ \\
\hline \multirow[t]{4}{*}{$\mathrm{ASO}$} & $0-30$ & $3.4 \pm 0.5$ & $66.5 \pm 2.5$ & $29.6 \pm 2.8$ & $0.7 \pm 0.1$ & $5.8 \pm 0.1$ & $42 \pm 23$ & $2.6 \pm 1.5$ & $12.6 \pm 3.9$ & $49.4 \pm 17.9$ \\
\hline & $30-60$ & $3.4 \pm 0.3$ & $74.8 \pm 0.5$ & $21.3 \pm 0.5$ & $0.6 \pm 0.1$ & $5.8 \pm 0.1$ & $29 \pm 4$ & $4.4 \pm 3.0$ & $13.4 \pm 2.1$ & $41.9 \pm 8.6$ \\
\hline & $60-90$ & $3.1 \pm 0.3$ & $75.6 \pm 5.6$ & $20.9 \pm 5.9$ & $0.6 \pm 0.1$ & $6.0 \pm 0.3$ & $44 \pm 14$ & $4.4 \pm 3.0$ & $10.0 \pm 4.0$ & $59.4 \pm 13.0$ \\
\hline & $90-120$ & $4.0 \pm 1.3$ & $81.6 \pm 7.1$ & $13.8 \pm 8.6$ & $0.5 \pm 0.1$ & $6.1 \pm 0.2$ & $75 \pm 40$ & $4.4 \pm 3.0$ & $12.3 \pm 0.6$ & $62.7 \pm 10.4$ \\
\hline
\end{tabular}

$\S$ Cation exchange capacity; ${ }^{\dagger}$ exchangeable.

Whole-profile soil C stocks across all sites ranged from 249 to $640 \mathrm{Mg} \mathrm{C} \mathrm{ha}^{-1}$ for a 0-1.2 $\mathrm{m}$ depth (Figure 2). Across the study sites, the position along the catena sequence was a significant factor at KAW and SONI only. At KAW, soil C stock in the toe slope $\left(640 \mathrm{Mg} \mathrm{C} \mathrm{ha}^{-1}\right)$ was greater than in the summit $\left(379 \mathrm{Mg} \mathrm{C} \mathrm{ha}^{-1}\right)$ but statistically similar to that in the mid-slope ( $\left.532 \mathrm{Mg} \mathrm{C}^{-1}\right)$. At SONI, the pattern of the distribution of soil C stock was similar as in the mid-slope $\left(483 \mathrm{Mg} \mathrm{C} \mathrm{ha}^{-1}\right)$ and in the toe slopes $\left(358 \mathrm{Mg} \mathrm{C} \mathrm{ha}^{-1}\right)$ exceeded in the summit $\left(249 \mathrm{Mg} \mathrm{Cha}^{-1}\right)$. However, no differences in the soil C stock among catena positions were found at ASO.

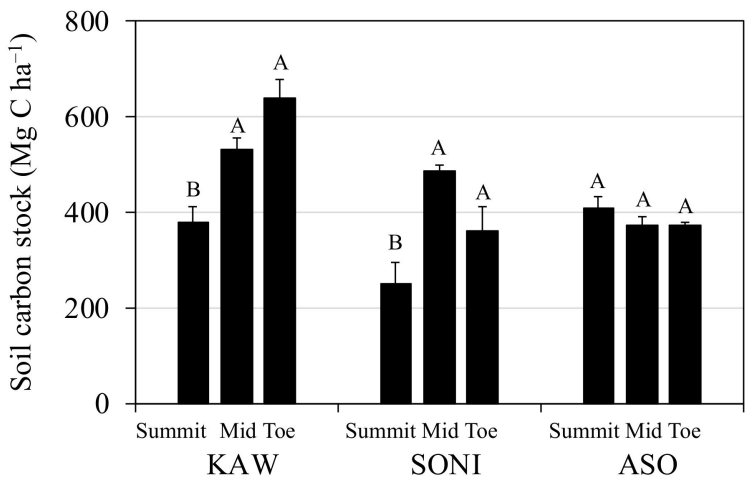

Figure 2. Profile summary of mean soil carbon stock along three catenas at semi-natural Miscanthus sinensis grassland sites in Japan (i.e., Kawatabi Field Science Center, Miyagi Prefecture (KAW); Soni Plateau, Nara Prefecture (SONI); Aso-Kuju National Park, Kumamoto Prefecture (ASO)). Error bars represent the standard errors. Statistically different means within a site are noted by means separation letters $(p<0.05)$.

Catena position was also a significant factor for soil $\mathrm{C}$ stocks at certain depths at each site (Figure 3, Supplement Table S1). At KAW, soil C stock in the toe slope was greater than that in the summit slope from 50 to $120 \mathrm{~cm}$ (Figure 3a), while it was higher in surface soil at the summit. At SONI, soil C stock in the mid-slopes demonstrated higher levels only between 50 and $100 \mathrm{~cm}$ depths, but it was statistically indistinguishable from toe slopes at most of these depths (Figure 3b). At ASO, a relatively higher soil C stock at the summit was observed from the surface down to a $20 \mathrm{~cm}$ depth (Figure 3). It was lower at the summit compared to those at the mid- and toe slopes from 30 to $80 \mathrm{~cm}$ depths of soil. Below $80 \mathrm{~cm}$ of soil, however, soil C stock increased and was higher at the summit. 


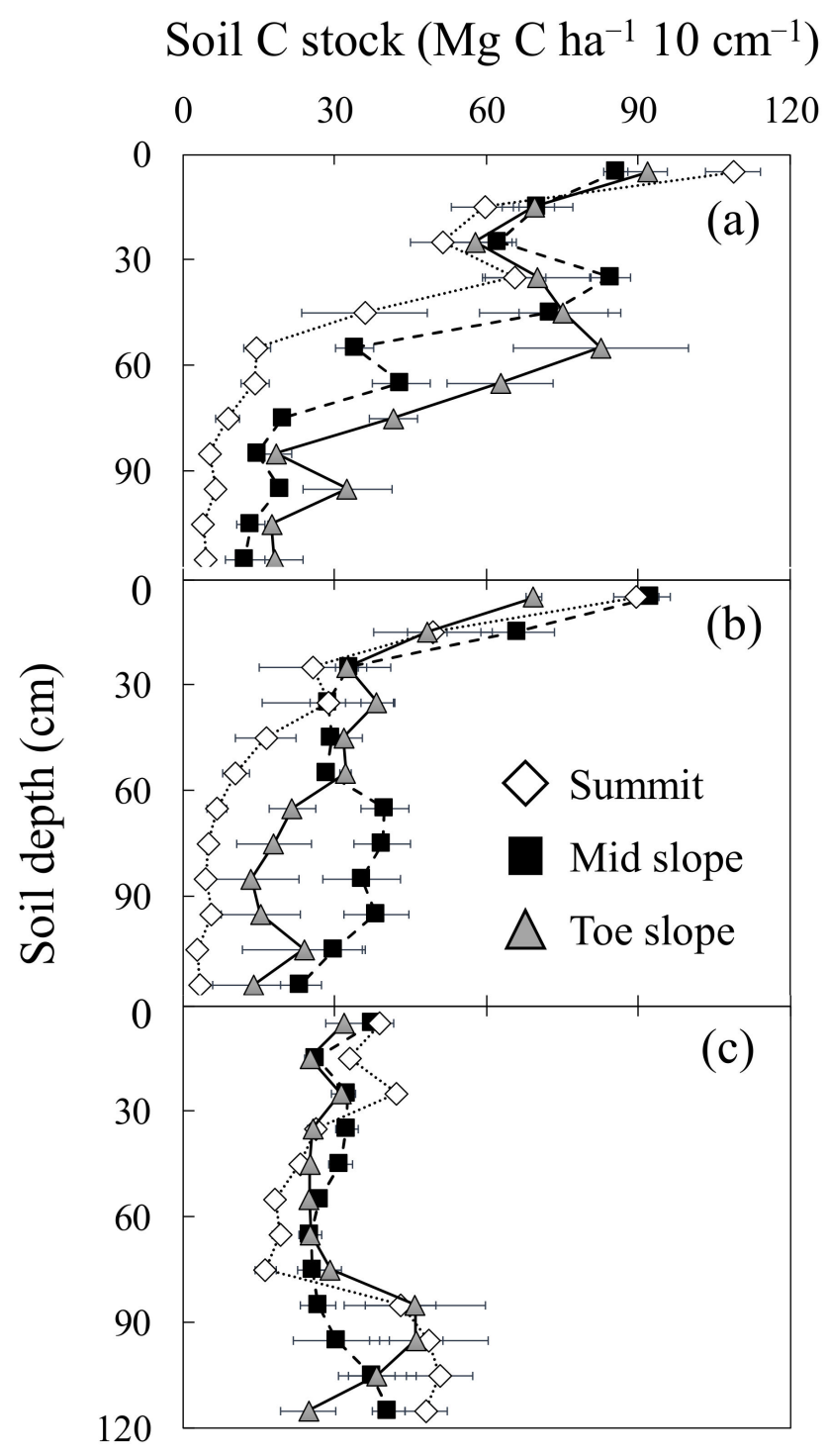

Figure 3. Soil carbon stock at $10 \mathrm{~cm}$ increments down to a $1.2 \mathrm{~m}$ depth for three positions along catenas at three semi-natural Miscanthus sinensis grassland sites in Japan: Kawatabi Field Science Center, Miyagi Prefecture (KAW) (a); Soni Plateau, Nara Prefecture (SONI) (b); Aso-Kuju National Park, Kumamoto Prefecture (ASO) (c). Error bars represent the standard errors.

The soil $\mathrm{C}$ accumulation rate for $\mathrm{C}_{4}$-based $\mathrm{C}$ across all sites within $10 \mathrm{~cm}$ soil depth increments ranged from 0.00 to $0.29 \mathrm{MgC} \mathrm{ha}^{-1} \mathrm{yr}^{-1}$ (Figure 4). Within each site, mean $\mathrm{C}_{4}-\mathrm{C}$ accumulation for the whole profile $(0-120 \mathrm{~cm}$ ) was $0.05 \pm 0.02$ (Average $\pm \mathrm{SE}$ ), $0.04 \pm 0.00$, and $0.24 \pm 0.04 \mathrm{MgC} \mathrm{ha}^{-1} \mathrm{yr}^{-1}$ at KAW, SONI, and ASO, respectively. At ASO, $\mathrm{C}_{4}-\mathrm{C}$ constituted the vast majority of total $C$, especially from 80 to $120 \mathrm{~cm}$ (Figure 4c). To a lesser extent, $\mathrm{KAW}$ soil $\mathrm{C}$ was mostly $\mathrm{C}_{4}-\mathrm{C}$ (Figure $4 \mathrm{a}$ ). In addition, $\mathrm{C}_{4}-\mathrm{C}$ closely followed the trend of total $\mathrm{C}$, decreasing in content from 40 to $80 \mathrm{~cm}$. At SONI, $\mathrm{C}_{4}-\mathrm{C}$ comprised the majority of total $C$ (Figure $4 b$ ). ASO had the highest mean content of $\mathrm{C}_{4}-\mathrm{C}$ at $86.3 \%$ (57.0-100\%) with KAW at 58.2\% (28.6-99.1\%) and SONI at 56.3\% (37.0-76.9\%). 


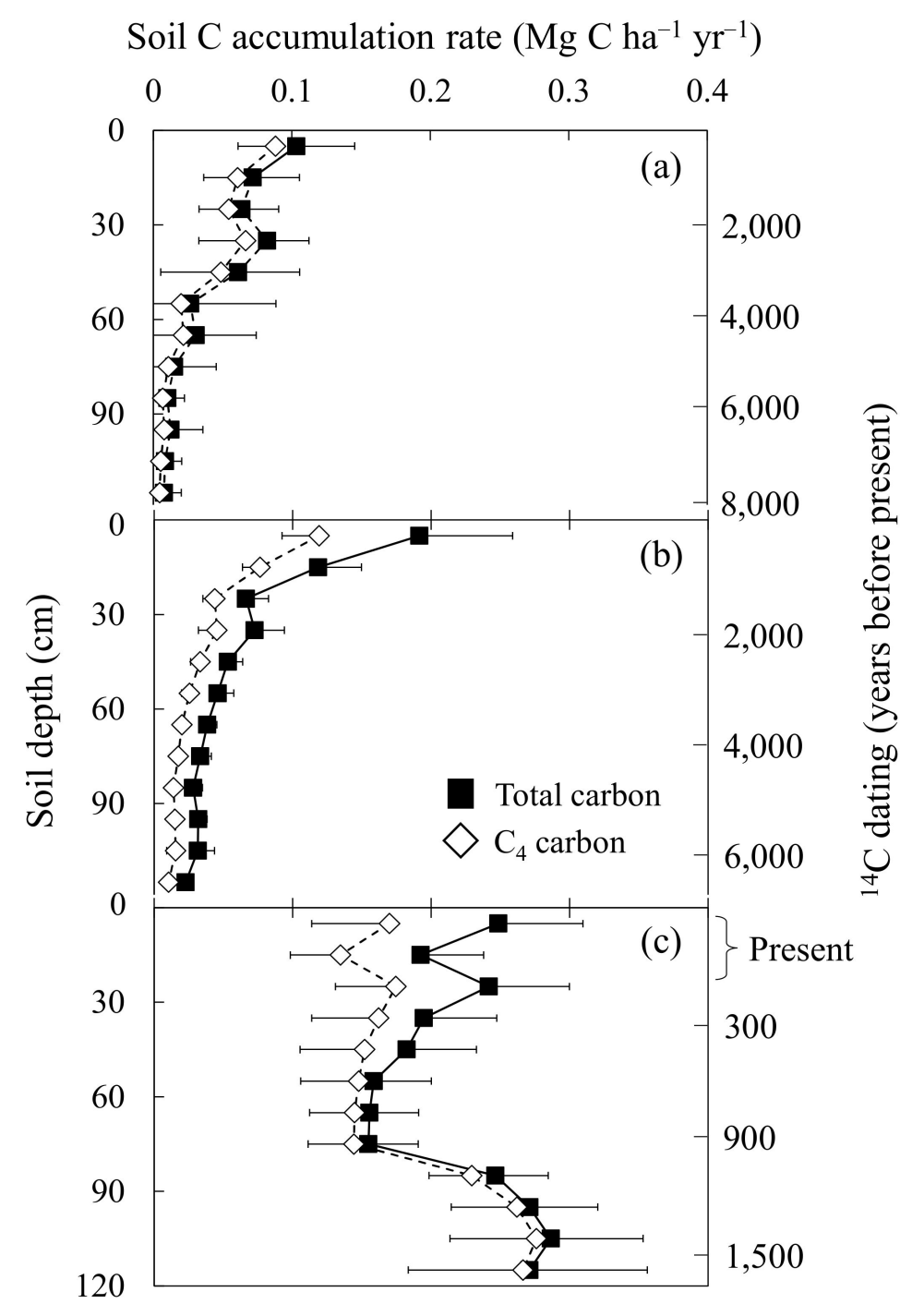

Figure 4. Soil carbon accumulation rate and relative soil age (years before present) for $\mathrm{C}_{4}$-derived $\mathrm{C}$ (clear diamonds) and total C (black squares) to a $1.2 \mathrm{~m}$ in three semi-natural Miscanthus sinensis grassland sites in Japan: Aso-Kuju National Park, Kyushu Prefecture (ASO) (a); Kawatabi Field Science Center, Miyagi Prefecture (KAW) (b); and Soni Plateau, Nara Prefecture (SONI) (c). Error bars represent the standard errors.

One major difference between ASO and the two other sites was the age of the bottom soil depth at $1.2 \mathrm{~m}$. At ASO, the age of the 110-120 cm depth was dated 1590 years before present, while the 110-120 cm depth at KAW and SONI was closer to 7836 and 6415 years before present, respectively (Figure 4). As such, the profiles at ASO represent a more recent portion of the age ranges found in the other sites (Figure 4). The age-to-depth models used to calibrate the soil ages throughout the profile were highly correlated with an $R^{2}$ in the range of $0.83-0.98$ and $p<0.05$ (Figure 5, Supplement Table S2). The only exception was the toe slope at SONI with an $R^{2}$ of 0.79 (Figure $5 b$ ). 


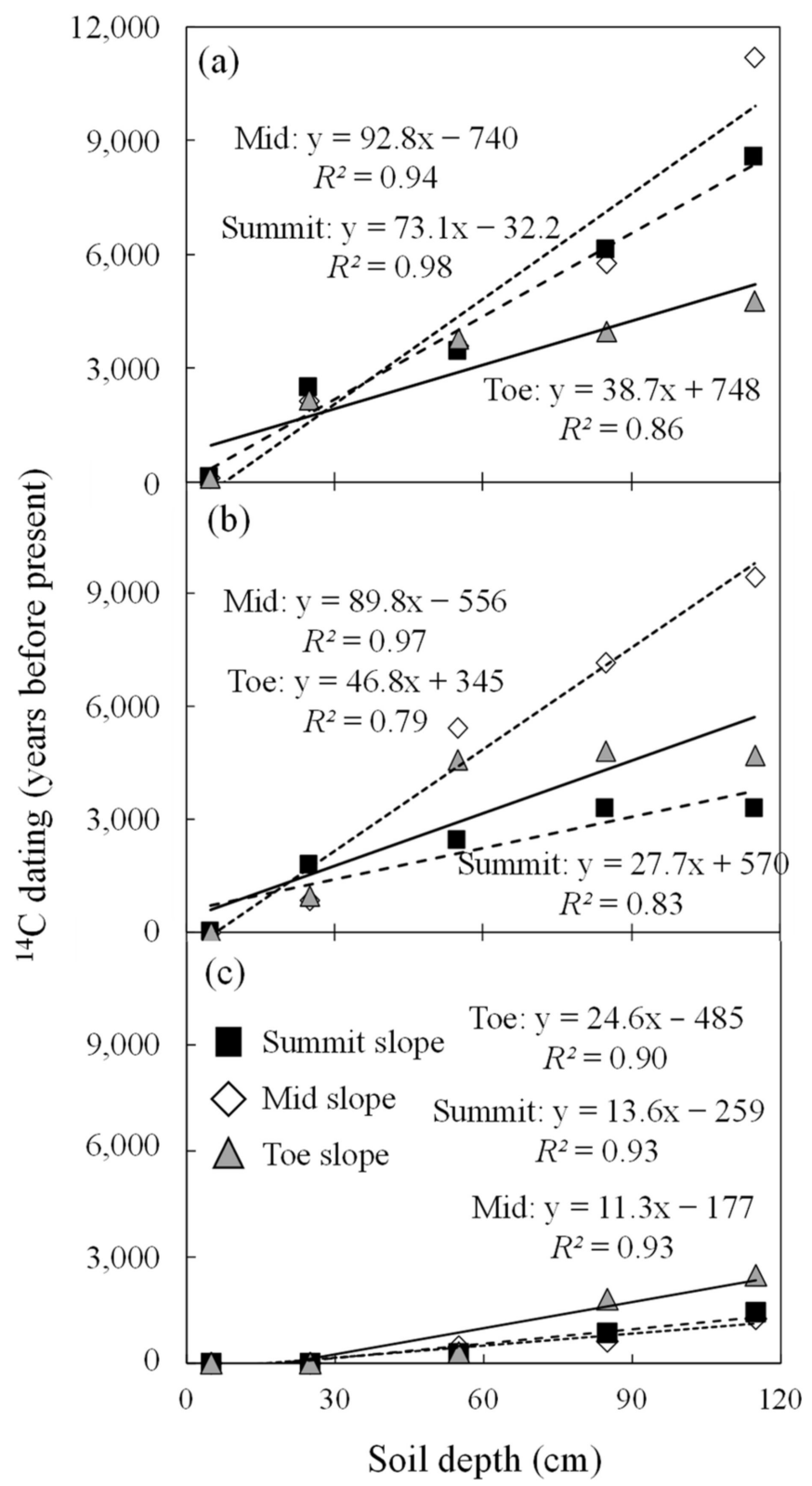

Figure 5. Calibrated radiocarbon ages to a $1.2 \mathrm{~m}$ depth of soil carbon at three catena positions (i.e., toe slope, mid-slope, and summit) in three semi-natural Miscanthus sinensis grassland sites in Japan: Kawatabi Field Science Center, Miyagi Prefecture (KAW) (a); Soni Plateau, Nara Prefecture (SONI) (b); Aso-Kuju National Park, Kyushu Prefecture (ASO) (c).

\section{Discussion}

\subsection{Soil Carbon Stock along Catena}

Soil C stocks in the $M$. sinensis-dominated grasslands of Japan appeared to be influenced by catena position along a toposequence. For total accumulated soil $\mathrm{C}$ stock for the 0-120 cm soil depths, toe and mid-slopes demonstrated a long-understood tendency to be the recipient of C-containing sediments from the summit (Figure 3) [21,22,34]. Jenny (1941) [34] indicated that erosion does not play a significant role in some well-vegetated catenas, given their minimal degree of erosion. However, the annual cultural practice of burning the $M$. sinensis grasslands in Japan reduces biotic control of erosion. Movement of sediment from organic horizons follows the course of gravity and increases $C$ stock in mid- and toes slopes (Figure 3). This may partially help explain the pattern of soil 
$\mathrm{C}$ accumulation found at KAW and SONI (Figure 3a,b). Upon further investigation of differences in soil $C$ stocks at various depths within the catenas, many of the differences seen in KAW and SONI only occurred below $60 \mathrm{~cm}$ depths (Figure 3a,b), coinciding with soil ages in the range of approximately 4000 years before present. Differences in soil $\mathrm{C}$ in deeper layers across different topographic positions unlikely reflect differences in current vegetation, because $M$. sinensis rhizomes and roots mainly populated the surface layer down to a $20 \mathrm{~cm}$ depth [35]. Because the age of $C$ in sediments at ASO was much younger than the other study sites, investigations of deeper soil profiles at ASO might be required to determine if catena position is a significant factor in determining soil C stocks at ASO, where no differences were found. While catena position does appear to affect soil $\mathrm{C}$ stock at KAW and SONI, the effect occurred between 4000 and 8000 years before present.

In all catena grasslands examined, very high total soil $\mathrm{C}$ stocks were found in upland (non-hydric) soils (up to $638 \mathrm{Mg} \mathrm{Cha}^{-1}$ ) (Figure 4). The likely presence of high contents of $\mathrm{Al}$ and $\mathrm{Fe}$ possibly contributed to large quantities of humus stabilization in the volcanic soils of this study $[11,36,37]$. Formation of recalcitrant organo-mineral complexes with $\mathrm{Al}$ and $\mathrm{Fe}$ reduces translocation and mineralization of $C$ in the soil $[38,39]$. This may also help explain how the relatively high amounts of sequestered $\mathrm{C}[36,40]$ and low $\mathrm{pH}(\sim 5)$, especially at $\mathrm{KAW}$, contributed to the formation of these complexes [41]. In addition, the presence of these organo-mineral complexes might possibly explain the relatively high correlations of determination that provided confidence to the sedimentation rate calculations used to estimate $C$ accumulation. Because we could not analyze the organo-mineral complexes with $\mathrm{Al}$ and $\mathrm{Fe}$ in this study, these analyses and evaluation need to be addressed in future research. Furthermore, regularly occurring fire events over hundreds of years at ASO and SONI may also have contributed to the stabilization of soil C. Burning has been shown to increase the stability of organic matter through the formation of highly condensed aromatic compounds [42]. Thus, the evaluation of soil humus characteristics could be important variables to include in future studies.

Toma et al. (2012) [13] and Howlett et al. (2013) [11] provided a broad review of work on $\mathrm{C}$ sequestration in soils where Miscanthus has been long established. Previous work at ASO demonstrated high total C stock levels down to a $1.5 \mathrm{~m}$ depth (515 and $559 \mathrm{Mg} \mathrm{C} \mathrm{ha}^{-1}$ ) in two soil profiles dated, at a maximum, to 12,000 years before present [11]. The site, characterized by Howlett et al. (2013) [11], was relatively flat where erosion appeared to not be a significant factor. We considered nine soil profiles at ASO only to a depth of $1.2 \mathrm{~m}$ on younger soils where humus may not have had as much time to accumulate. As such, the results reported here appear to be consistent with previous work at ASO [11]. However, as with the site studied by Howlett et al. (2013) [11], there appears to be a buried organic soil horizon nearly $80 \mathrm{~cm}$ below the soil surface as reflected by the notable increase in soil $\mathrm{C}$ accumulation rates starting at that depth (Figure 4c). Basile-Doelsch et al. (2005) [43] reported high soil C stock levels $100 \mathrm{~cm}$ belowground of a volcanic-ash soil, which was located adjacent to the Piton des Neiges volcano on the island of La Reunion, where a burial event occurred sometime in the distant past.

\subsection{Source and Rate of Carbon Accumulation}

We assumed, for the purpose of this study, that all $\mathrm{C}_{4}-\mathrm{C}$ was derived from Miscant$h u s$, as no other known species in the study areas utilize the $\mathrm{C}_{4}$ photosynthetic pathway. Miyabuchi and Sugiyama (2006) [44] detailed the dominance of $M$. sinensis via plant phytolith analysis in semi-natural grasslands located on the east side of the Aso caldera in Aso-Kuju National Park. While accumulation of $C$ from $C_{4}$ sources follows the trend of total soil $\mathrm{C}$ accumulation throughout the profiles examined here, the content of $\mathrm{C}_{4}$ - $\mathrm{C}$ varied considerably among sites (Figure 4). Soil at ASO had the highest amount of $\mathrm{C}_{4^{-}}$ derived $C$ accumulation, representing nearly $100 \%$ of $C$ from 70 to $120 \mathrm{~cm}$ (Figure 4c). The $\mathrm{C}_{4}-\mathrm{C}$ and total-C accumulation trends at $\mathrm{KAW}$ and $\mathrm{SONI}$ underscore the importance of Miscanthus-derived C, but since not all $\mathrm{C}$ was from $\mathrm{C}_{4}$ sources, additions of $\mathrm{C}$ from non-Miscanthus sources were consistent with the presence of other plant species over time. 
Although currently dominated by $M$. sinensis, the composition of vegetative inputs in the plant community to soil $C$ varied over the 12,000 year period $[11,25]$. At SONI, previous work identified charcoal remnants from anthropogenic fires that began around 7000 years before present with phytolith data indicating a vegetative shift [25]. If $\mathrm{C}_{4}-\mathrm{C}$ was mostly Miscanthus-derived, the general increase in $\mathrm{C}_{4}$-C accumulation at KAW (Figure $4 \mathrm{a}$ ) may indicate a vegetative change from forest to grassland, which may have promoted more $\mathrm{C}$ storage in soil $\mathrm{C}$ pools relative to aboveground biomass $[13,45,46]$.

Rates of Miscanthus-source soil C accumulation, highest at ASO, may be an indication of the greater net primary production that occurred under warmer and nearly double the precipitation than that observed at SONI and KAW (Figure 4). Howlett et al. (2013) [11] measured soil $\mathrm{C}$ accumulation at $\mathrm{ASO}$ on a site $14 \mathrm{~km}$ northwest of the current study site and found mean $\mathrm{C}_{4}-\mathrm{C}$ accumulation rates between 0.62 and $0.85 \mathrm{Mg} \mathrm{C}^{-1} \mathrm{yr}^{-1}$ down to $1.5 \mathrm{~m}$ in the soil. These previously studied profiles likely represented several buried organic horizons dating to approximately 12,000 years before present, where humus accumulation occurred over an extensive period. As mentioned above, a similar phenomenon appears to have occurred at the current study site, where a buried organic horizon appears nearly $80 \mathrm{~cm}$ below the soil surface but is considerably younger (Figure 4c).

As suggested by Chaopricha and Marin-Spiotta (2014) [47], soil burial is a globally important, yet largely underestimated, process involved in the storage and persistence of substantial $\mathrm{C}$ stocks in soils. Indeed, volcanic soils buried $3 \mathrm{~m}$ below the surface on the slopes of Mount Kilimanjaro were estimated to contain $820 \mathrm{Mg} \mathrm{C}^{-1}$ [48]. In addition, Inoue et al. (2000) [49] found that high soil C levels, which were buried multiple times over for several thousand years in a volcanic basin $135 \mathrm{~km}$ south of Aso, had not substantially decreased since the initial burial events. Similarly, based on our data and that of Howlett et al. (2013) [11], we strongly suspect that large reservoirs of C are stored in buried soils throughout the Aso volcanic caldera. Indeed, several volcanic eruptions have occurred in the ASO area over the past several thousand years, including several that occurred in the early 1200s [50], which coincide with the putative burial event seen in the soil profile at the current study site. These events suggest that soil burial due to the soil sedimentation resulting in volcanic ash deposition and plant residue accumulation acts as an important process in maintaining soil $\mathrm{C}$ levels at deeper soil layers under the stable thermal environments and anaerobic conditions. Possibly due to the more recent eruption event, the current study site had much more ash deposition in the subsurface soil than the study site of Howlett et al. (2013) [11], which was likely due to the current site being $6.3 \mathrm{~km}$ closer to the volcano at Aso. Moreover, more ash deposition likely occurred given the westto-east prevailing wind direction in the region. The study site of Howlett et al. (2013) [11] was $15.9 \mathrm{~km}$ north of the volcano, whereas the current study site was $9.7 \mathrm{~km}$ east of the volcano. In this study, we report $\mathrm{C}_{4}-\mathrm{C}$ accumulation rates that were 3-4 times lower than that reported by Howlett et al. (2013) [11]. Given that the soil-C measurements of the current study were taken to only a $1.2 \mathrm{~m}$ depth in comparatively younger soils (to 1590 years before present) at ASO may explain the lower soil C accumulation rates. Zehetner (2010) [51] reported that soil $C$ accumulation rates can range between 0.3 and $0.6 \mathrm{Mg} \mathrm{C} \mathrm{ha}^{-1} \mathrm{yr}^{-1}$ in relatively volcanic-ash soils. However, most studies on soil C accumulation in cultivated Miscanthus fields have reported considerably higher rates. Soils where $M$. sinensis had been established for 6 [7] and 14 years [52] under managed conditions in southeastern England accumulated $\mathrm{C}$ at approximately $0.80 \mathrm{Mg} \mathrm{ha}^{-1} \mathrm{yr}^{-1}$, which is similar to what Poeplau and Don (2014) [53] found in an analysis of six Miscanthus plantations $\geq 10$ years old across Europe $\left(0.78 \mathrm{Mg} \mathrm{ha}^{-1} \mathrm{yr}^{-1}\right)$. In addition, based on 23 data sets, Agostini et al. (2015) and Qin et al. (2016) [54] both calculated global estimates of C accumulation under Miscanthus to be approximately $1.2 \mathrm{Mg} \mathrm{ha}^{-1} \mathrm{yr}^{-1}$. Differences in soil clay content, soil bulk density, and initial low $\mathrm{C}$ stocks between the semi-natural Miscanthus grassland site and the primarily managed fields in these other studies may have led to considerable differences in soil C sequestration [55-57]. In addition, given that the managed fields were amended with fertilizer, this undoubtedly contributed to the differences in soil $\mathrm{C}$ sequestration rates. 
KAW and SONI had mean $\mathrm{C}_{4}-\mathrm{C}$ accumulation rates roughly an order of magnitude less than ASO. These colder, more northern latitude sites, with half the precipitation of ASO, likely have lower net primary production. As such, potential C inputs to the soil would be expected to be lower.

\section{Conclusions}

As Miscanthus becomes more widely planted outside its native range, particularly in low soil $\mathrm{C}$ agronomic fields, the potential exists for sequestration of $\mathrm{C}$ over the long term. Moreover, anthropogenic fire events, which are used to maintain vegetation, may further increase soil C. Toposequence along a catena influence soil C stocks in $M$. sinensis grasslands in its native range of Japan. Consideration of $\mathrm{C}$ sequestration in cultivated Miscanthus fields should include characterization of topographic variability. A majority of soil $\mathrm{C}$ in the grasslands examined appears to have derived from $\mathrm{C}_{4}-\mathrm{C}$. In addition, accumulation rates for $\mathrm{C}_{4}-\mathrm{C}$ were lower than previously demonstrated.

Supplementary Materials: The following supporting information can be downloaded at: https: / / www.mdpi.com/article/10.3390/agriculture12010088/s1, Table S1: Calibrated radiocarbon ages to $1.2 \mathrm{~m}$ depth of soil carbon at three catena positions (toe slope, mid slope, and summit) in three semi-natural Miscanthus sinensis grassland sites in Japan: Kawatabi Field Science Center, Miyagi Pre-fecture (KAW), and Soni Plateau, Nara Prefecture (SONI), and Aso-Kuju National Park, Kyushu Prefecture (ASO); Table S2: Calibrated radiocarbon ages to $1.2 \mathrm{~m}$ depth of soil carbon at three catena positions (toe slope, mid slope, and summit) in three semi-natural Miscanthus sinensis grassland sites in Japan: Kawatabi Field Science Center, Miyagi Pre-fecture (KAW), and Soni Plateau, Nara Prefecture (SONI), and Aso-Kuju National Park, Kyushu Prefecture (ASO).

Author Contributions: Conceptualization, D.S.H., J.R.S., T.Y., F.G.F. and Y.T.; methodology, D.S.H., J.R.S., J.I., M.S., A.N., F.G.F. and Y.T.; software, D.S.H.; validation, D.S.H. and Y.T.; formal analysis, D.S.H., H.W. and Y.T.; investigation, D.S.H., J.I., M.S. and Y.T.; resources, J.R.S., D.L., H.W., T.Y. and F.G.F.; data curation, D.S.H., J.R.S. and Y.T.; writing — original draft preparation, D.S.H.; writingreview and editing, D.S.H., J.R.S., J.I., T.Y., F.G.F., M.S. and Y.T.; visualization, D.S.H. and Y.T.; supervision, J.R.S. and Y.T.; project administration, J.R.S. and T.Y.; funding acquisition, J.R.S. and T.Y. All authors have read and agreed to the published version of the manuscript.

Funding: This project was funded by the Energy Biosciences Institute at the University of Illinois through a grant from the British Petroleum Corporation.

Acknowledgments: We would like to thank Makoto Nakaboh, and his staff at the Kyushu Biomass Forum for providing assistance to our field research. We would also like to express our appreciation to the Aso Environmental Office and owners of the study site in Aso, Kumamoto, Japan; student workers at Kawatabi Field Science Center; the Geology Department of Osaka City University; Carolina Bueno Wandscheer, who provided invaluable assistance to field collections.

Conflicts of Interest: The authors declare no conflict of interest. The funders had no role in the design of the study; in the collection, analyses, or interpretation of data; in the writing of the manuscript or in the decision to publish the results.

\section{References}

1. Clifton-Brown, J.; Hastings, A.; Mos, M.; McCalmont, J.P.; Ashman, C.; Awty-Carroll, D.; Cerazy, J.; Chiang, Y.C.; Cosentiono, S.; Cracroft-Eley, W.; et al. Progress in upscaling Miscanthus biomass production for the European bio-economy with seed-based hybrids. Glob. Chang. Biol. Bioenergy 2017, 9, 6-17. [CrossRef]

2. Huang, L.S.R.; Flavell, R.; Donnison, I.S.; Chiang, Y.C.; Hastings, A.; Hayes, C.; Heidt, C.; Hong, H.; Hsu, T.W.; Humphreys, M.; et al. Collecting wild Miscanthus germplasm in Asia for crop improvement and conservation in Europe whilst adhering to the guidelines of the United Nations' Convention on Biological Diversity. Ann. Bot. 2018, 124, 591-604. [CrossRef]

3. Somerville, C.; Youngs, H.; Taylor, C.; Davis, S.C.; Long, A.P. Feedstocks for lignocellulosic biofuels. Science 2010, 329, 790-792. [CrossRef] [PubMed]

4. Stewart, J.R.; Toma, Y.; Fernández, F.G.; Nishiwaki, A.; Yamada, T.; Bollero, G. The ecology and agronomy of Miscanthus sinensis, a species important to bioenergy crop development, in its native range in Japan: A review. Glob. Chang. Biol. Bioenergy 2009, 1, 126-153. [CrossRef] 
5. Agostini, F.; Gregory, A.S.; Richter, G.M. Carbon sequestration by perennial energy crops: Is the jury still out? BioEnergy Res. 2015, 8, 1057-1080. [CrossRef]

6. Clifton-Brown, J.C.; Breur, L.; Jones, M.B. Carbon mitigation by the energy crop. Miscanthus. Glob. Change Biol. 2007, 13, 2296-2307. [CrossRef]

7. Gregory, A.S.; Dungait, J.A.J.; Shield, I.F.; Macalpine, W.J.; Cunniff, J.; Durenkamp, M.; White, R.P.; Joynes, A.; Richter, G.M. Species and genotype effects of bioenergy crops on root production, carbon and nitrogen in temperate agricultural soil. Bioenergy Res. 2018, 11, 382-397. [CrossRef]

8. Hansen, E.M.; Christensen, B.T.; Jensen, L.S.; Kristensen, K. Carbon sequestration in soil beneath long-term Miscanthus plantations as determined by ${ }^{13} \mathrm{C}$ abundance. Biomass Bioenergy 2004, 26, 97-105. [CrossRef]

9. Schneckenberger, K.; Kuzyakov, Y. Carbon sequestration under Miscanthus in sandy and loamy soils estimated by natural ${ }^{13} \mathrm{C}$ abundance. J. Plant Nutr. Soil Sci. 2007, 170, 538-542. [CrossRef]

10. Anzoua, K.G.; Suzuki, K.; Fujita, S.; Toma, Y.; Yamada, T. Evaluation of morphological traits, winter survival and biomass potential in wild Japanese Miscanthus sinensis Anderss. populations in northern Japan. Grassl. Sci. 2015, 61, 83-91. [CrossRef]

11. Howlett, D.S.; Toma, Y.; Wang, H.; Sugiyama, S.; Yamada, T.; Nishiwaki, A.; Fernández, F.G.; Stewart, J.R. Soil carbon source and accumulation over 12,000 years in a semi-natural Miscanthus sinensis grassland in southern Japan. Catena 2013, 104, 127-135. [CrossRef]

12. Toma, Y.; Yamada, T.; Fernández, F.G.; Nishiwaki, A.; Hatano, R.; Stewart, J.R. Evaluation of greenhouse gas emissions in a Miscanthus sinensis Andersson-dominated semi-natural grassland in Kumamoto, Japan. Soil Sci. Plant Nutr. 2016, 62, 80-89. [CrossRef]

13. Toma, Y.; Armstrong, K.; Stewart, J.R.; Yamada, T.; Nishiwaki, A.; Fernández, F.G. Carbon sequestration in soil in a semi-natural Miscanthus sinensis grassland and Cryptomeria japonica forest plantation in Aso, Kumamoto, Japan. Glob. Chang. Biol. Bioenergy 2012, 4, 566-575. [CrossRef]

14. Toma, Y.; Fernández, F.G.; Sato, S.; Izumi, M.; Hatano, R.; Yamada, T.; Nishiwaki, A.; Bollero, G.; Stewart, J.R. Carbon budget and methane and nitrous oxide emissions over the growing season in a Miscanthus sinensis grassland in Tomakomai, Hokkaido, Japan. Glob. Chang. Biol. Bioenergy 2011, 3, 116-134. [CrossRef]

15. Toma, Y.; Fernández, F.G.; Nishiwaki, A.; Yamada, T.; Bollero, G.; Stewart, J.R. Aboveground plant biomass, carbon, and nitrogen dynamics before and after burning in a seminatural grassland of Miscanthus sinensis in Kumamoto, Japan. Glob. Chang. Biol. Bioenergy 2010, 2, 52-62. [CrossRef]

16. Boutton, T.W.; Archer, S.R.; Midwood, A.J.; Zitzer, S.F.; Bol, R. $\delta^{13} \mathrm{C}$ values of soil organic carbon and their use in documenting vegetation change in a subtropical savanna ecosystem. Geoderma 1998, 82, 5-41. [CrossRef]

17. Farquhar, G.; Ehleringer, J.; Hubick, K. Carbon isotope discrimination and photosynthesis. Annu. Rev. Plant Physiol. Plant Mol. Biol. 1989, 40, 503-537. [CrossRef]

18. Fry, B. Stable Isotope Ecology, 1st ed.; Springer Science \& Business Media: New York, NY, USA, 2007.

19. Wang, H.; Hackley, K.C.; Panno, S.V.; Coleman, D.D.; Liu, J.C.L.; Brown, J. Pyrolysis-combustion ${ }^{14}$ C dating of soil organic matter. Quat. Res. 2003, 60, 348-355. [CrossRef]

20. Wang, Y.; Amundson, R.; Trumbore, S. Radiocarbon dating of soil organic matter. Quat. Res. 1996, 45, 282-288. [CrossRef]

21. Berhe, A.A.; Barnes, R.T.; Six, J.; Marin-Spiotta, E. Role of soil erosion in biogeochemical cycling of essential elements: Carbon, nitrogen, and phosphorus. Annu. Rev. Earth Planet. Sci. 2018, 46, 521-548. [CrossRef]

22. Schimel, D.; Stillwell, M.A.; Woodmansee, R.G. Biogeochemistry of C, N, and P in a soil catena of the shortgrass steppe. Ecology 1985, 66, 276-282. [CrossRef]

23. Ito, T.; Saigusa, M. Characteristics of nonallophanic andisols at Tohoku University Farm. Bull. Exp. Farm Tohoku Univ. 1996, 12, 91-103, (In Japanese with English Summary).

24. Inoue, J.; Nishimura, R.; Takahara, H. A 7500-year history of intentional fires and changing vegetation on the Soni Plateau, Central Japan, reconstructed from macroscopic charcoal and pollen records within mire sediment. Quat. Int. 2012, 254, 12-17. [CrossRef]

25. Okunaka, R.; Kawano, T.; Inoue, J. Holocene history of intentional fires and grassland development on the Soni Plateau, Central Japan, reconstructed from phytolith and macroscopic charcoal records within cumulative soils, combined with paleoenvironmental data from mire sediments. Holocene 2012, 22, 793-800. [CrossRef]

26. Miyabuchi, Y.; Sugiyama, S.; Nagaoka, Y. Vegetation and fire history during the last 30,000 years based on phytolith and macroscopic charcoal records in the eastern and western areas of Aso Volcano, Japan. Quat. Int. 2012, 254, 28-35. [CrossRef]

27. USDA NRCS. Keys to Soil Taxonomy; United States Department of Agriculture: Washington, DC, USA, 2014.

28. Miyabuchi, Y. A 90,000-year tephrostratigraphic framework of Aso Volcano, Japan. Sediment. Geol. 2009, 220, 169-189. [CrossRef]

29. Brandt, S.A.; Fisher, F.C.; Hildebrand, E.A.; Vogelsang, R.; Ambrose, S.H.; Lesur, J.; Wang, H. Early MIS 3 occupation of Mochena Borago Rockshelter, Southwest Ethiopian Highlands: Implications for Late Pleistocene archaeology, paleoenvironments and modern human dispersals. Quat. Int. 2012, 274, 38-54. [CrossRef]

30. Southon, J. Graphite reactor memory-Where is it from and how to minimize it? Nucl. Instrum. Methods Phys. Res. Sect. B Beam Interact. Mater. Atoms 2007, 259, 288-292. [CrossRef]

31. Stuiver, M.; Polach, H.A. Discussion reporting of 14C Data. Radiocarbon 1977, 19, 355-363. [CrossRef]

32. Eshel, G.; Levy, G.J.; Mingelgrin, U.; Singer, M.J. Critical evaluation of the use of laser diffraction for particle-size distribution analysis. Soil Sci. Soc. Am. J. 2004, 68, 736-743. [CrossRef] 
33. Bray, R.H.; Kurtz, L.T. Determination of total, organic, and available forms of phosphorus in soils. Soil Sci. 1945, 59, 39-45. [CrossRef]

34. Jenny, H. Factors of Soil Formation: A System of Quantitative Pedology; McGraw-Hill: New York, NY, USA, 1942.

35. Yano, N. On the subterranean organ of wild plants of grassland, I. Miscanthus sinensis Andresson. Jpn. J. Grassl. Sci. 1965, 11, 48-54, (In Japanese with English Summary). [CrossRef]

36. Dahlgren, R.A.; Saigusa, M.; Ugolini, F.C. Advances in Agronomy: The Nature, Properties and Management of Volcanic Soils; Elsevier Academic Press Inc.: San Diego, CA, USA, 2004.

37. Dahlgren, R.A.; Ugolini, F.C.; Shoji, S.; Ito, T.; Sletten, R.S. Soil-forming processes in Alic Melanudands under Japanese pampas grass and oak. Soil Sci. Soc. Am. J. 1991, 55, 1049-1056. [CrossRef]

38. Matus, F.; Rumpel, C.; Neculman, R.; Panichini, M.; Mora, M.L. Soil carbon storage and stabilisation in andic soils: A review. Catena 2014, 120, 102-110. [CrossRef]

39. Pena-Ramirez, V.M.; Vazquez-Selem, L.; Siebe, C. Soil organic carbon stocks and forest productivity in volcanic ash soils of different age (1835-30,500 years BP) in Mexico. Geoderma 2009, 149, 224-234. [CrossRef]

40. Boudot, J.P.; Hadj, B.A.B.; Chone, T. Carbon mineralization in andosols and aluminium-rich highland soils. Soil Biol. Biochem. 1986, 18, 457-461. [CrossRef]

41. Shoji, S.; Kurebayashi, T.; Yamada, I. Growth and chemical composition of Japanese pampas grass (Miscanthus sinensis) with special reference to the formation of dark-colored andisols in northeastern Japan. Soil Sci. Plant Nutr. 1990, 36, 105-120. [CrossRef]

42. Johnson, W.C. Sequestration in buried soils. Nat. Geosci. 2014, 7, 398-399. [CrossRef]

43. Basile-Doelsch, I.; Amundson, R.; Stone, W.E.E.; Masiello, C.A.; Bottero, J.Y.; Colin, F.; Masin, F.; Borschneck, D.; Meunier J.D. Mineralogical control of organic carbon dynamics in a volcanic ash soil on La Reunion. Eur. J. Soil Sci. 2005, 56, 689-703. [CrossRef]

44. Miyabuchi, Y.; Sugiyama, S. A 30,000-year phytolith record of a tephra sequence, east of Aso caldera, Southwestern Japan. Quant. Res. 2006, 45, 15-28, (In Japanese with English Summary). [CrossRef]

45. Guo, L.B.; Gifford, R.M. Soil carbon stocks and land use change: A meta analysis. Glob. Change Biol. 2002, 8, 345-360. [CrossRef]

46. Howlett, D.S.; Mosquera-Losada, M.R.; Nair, P.K.R.; Nair, V.D.; Rigueiro-Rodríguez, A. Soil carbon storage in silvopastoral systems and a treeless pasture in northwestern Spain. J. Environ. Qual. 2011, 40, 825-832. [CrossRef]

47. Chaopricha, N.T.; Marin-Spiotta, E. Soil burial contributes to deep soil organic carbon storage. Soil Biol. Biochem. 2014, 69, 251-264 [CrossRef]

48. Zech, M.; Horold, C.; Leiber-Sauheitl, K.; Kuhnel, A.; Andreas, H.; Zech, W. Buried black soils on the slopes of Mt. Kilimanjaro as a regional carbon storage hotspot. Catena 2014, 112, 125-130. [CrossRef]

49. Inoue, Y.; Sugiyama, S.; Nagatomo, Y. Organic carbon content and phytolith in a cumulative Andisols in Miyakonojo Basin, Japan. Pedologist 2000, 44, 109-123, (In Japanese with English Summary). [CrossRef]

50. Smithsonian Institution Asosan. Available online: https://volcano.si.edu/volcano.cfm?vn=282110 (accessed on 14 November 2021).

51. Zehetner, F. Does organic carbon sequestration in volcanic soils offset volcanic $\mathrm{CO}_{2}$ emissions? Quat. Sci. Rev. 2010, 29 , 1313-1316. [CrossRef]

52. Richter, G.M.; Agostini, F.; Redmile-Gordon, M.; White, R.; Goulding, K.W.T. Sequestration of C in soils under Miscanthus can be marginal and is affected by genotype-specific root distribution. Agric. Ecosyst. Environ. 2015, 200, 169-177. [CrossRef]

53. Poeplau, C.; Don, A. Soil carbon changes under Miscanthus driven by $\mathrm{C}_{4}$ accumulation and $\mathrm{C}_{3}$ decompostion-Toward a default sequestration function. Glob. Chang. Biol. Bioenergy 2014, 6, 327-338. [CrossRef]

54. Qin, Z.C.; Dunn, J.B.; Kwon, H.Y.; Mueller, S.; Wander, M.M. Soil carbon sequestration and land use change associated with biofuel production: Empirical evidence. Glob. Chang. Biol. Bioenergy 2016, 8, 66-80. [CrossRef]

55. Campbell, J.E.; Lobell, D.B.; Genova, R.C.; Field, C.B. The global potential of bioenergy on abandoned agriculture lands. Environ. Sci. Technol. 2008, 42, 5791-5794. [CrossRef]

56. Six, J.; Conant, R.T.; Paul, E.A.; Paustian, K. Stabilization mechanisms of soil organic matter: Implications for C-saturation of soils. Plant Soil 2002, 241, 155-176. [CrossRef]

57. Six, J.; Elliott, E.T.; Paustian, K. Soil macroaggregate turnover and microaggregate formation: A mechanism for C sequestration under no-tillage agriculture. Soil Biol. Biochem. 2000, 32, 2099-2103. [CrossRef] 